\title{
Biodiversity from mountain building
}

To the Editor - Long-term environmental stability has long been thought to lead to the accumulation of species and, therefore, higher diversity ${ }^{1}$. However, species richness and the time available for speciation often do not correlate across the tree of life ${ }^{2}$. Instead, it has emerged that geologically dynamic (rather than stable) areas around the world sustain higher biodiversity ${ }^{3-5}$. We argue that mountain building, driven by plate tectonics or volcanism, creates landscape and climatic changes, ecological gradients and physical habitats that set the stage for species evolution.

Mountains have a direct impact on biodiversity. They act as barriers to some organisms and bridges to others. As a mountain chain grows, it may separate previously coherent areas and their populations ${ }^{6}$, thus isolating species. Or it may connect land masses, favouring species migration ${ }^{7}$. Biodiversity in mountain belts is determined by the interplay between migration, speciation and extinction. As mountain habitats form, speciation bursts occur, driven by the requirement to adapt to the new environment ${ }^{8}$. Although the resulting species are often specialized to a small area ${ }^{3,9}$, mountain species can experience lower rates of extinction during climatic changes because they need to move considerably shorter distances to track their optimal temperature range as compared with lowland species $^{9}$. Because biodiversity is often high in a mountain region - a result of high speciation and low extinction - there is a raised likelihood of some species dispersing to other areas. In this scenario, mountains can turn into species pumps that feed the rest of their continents ${ }^{10}$.

Mountains also affect biodiversity indirectly. Uplift of Earth's surface during mountain growth influences drainage patterns ${ }^{11}$, generating drainage divides and rivers that in turn act as bridges, barriers or species pumps ${ }^{12}$. Mountain uplift also affects atmospheric circulation ${ }^{13}$ and the marine environment ${ }^{14}$. The Andean chain and the Amazon River are good examples of this interaction. Along the western margin of South America, the Andes grew into a high mountain range, whereas farther east the continent subsided and the Amazon Basin formed. Mountain and basin formation, as well as erosion, marine incursions and orographic precipitation ${ }^{13,15}$, together provide the nutrient-rich sediments and soils that now sustain the high species richness of

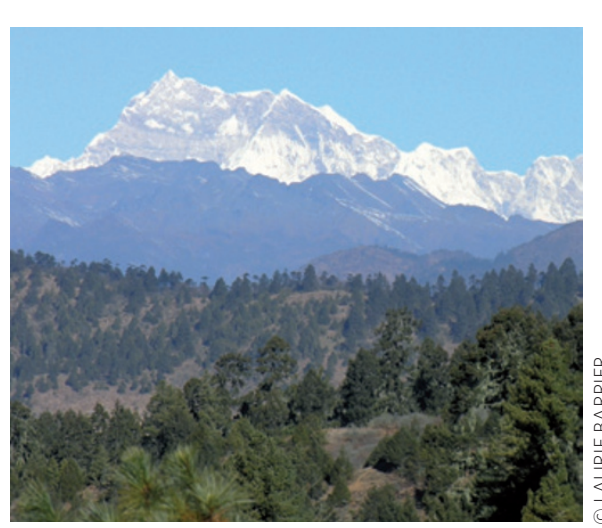

We must now work out which geological processes are most relevant, and how geology and climate together influence the evolutionary process. New molecular techniques, advanced reconstructions of Earth surface processes and a growing scientific interest in interdisciplinary projects will open new avenues to explore how uplift of the world's mountains interacts with biodiversity.

References

1. Simpson, G. G. Splendid Isolation: The Curious History of South American Mammals (Yale Univ. Press, 1980).

2. Rabosky, D. L., Slater, G. J. \& Alfaro, M. E. PLoS Biol. 10, e1001381 (2012).

Amazonia $^{16,17}$. From its formation about 10.5 million years ago $^{18}$, the Amazon River opened up entirely new habitats both on land and at sea. The Amazon Basin was initially a wetland environment, rich with mollusc fauna and fringed by forest. As the Andes continued to uplift and erode, the Amazon Basin filled with sediment and changed into a fluvial environment, wiping out most molluscs but making way for a highly diverse range of species adapted to non-flooded areas $^{17}$. In the Atlantic, the Amazon Plume the seaward extension of the Amazon River - created new geochemical conditions ${ }^{18}$ and prolific algal blooms ${ }^{19}$.

Plate tectonic reshuffling triggers a domino effect that ripples through biotic evolution.

The evidence from the Andes and Amazonia suggests that the development of other mountain belts, such as the Himalayas, Zagros Mountains and Southern Alps, also favoured a rise in biodiversity. Of course, it would be misleading to pin biodiversity entirely on extrinsic, abiotic processes ${ }^{20}$. Speciation of a group of alpine plants, for instance, may have more to do with adaptation to different pollinators than anything else - but if there were no mountains in the first place, there would be no alpine species.

Geological and biological sciences must be integrated to understand the distribution and evolution of biodiversity across the globe, on different spatial, temporal and taxonomic scales. A hundred years ago, Alfred Wegener advocated an interdisciplinary approach when he first spoke publicly about his theory of continental drift ${ }^{21}$. He was initially vilified and segregation progressed further, but following a long separation between biological and geological sciences, awareness is now rising that geological processes related to mountain building have decisively affected biodiversity patterns.
3. Fjeldså, J., Bowie, C. K. R. \& Rahbek, C. Annu. Rev. Ecol. Syst. 43, 249-265 (2012)

4. Linder, H. P. Phil. Trans. R. Soc. B Biol. Sci. 363, 3097-3105 (2008).

5. Badgley, C. Ecography 33, 220-231 (2010).

6. Weir, J. T. \& Price, M. Mol. Ecol. 20, 4550-4563 (2011).

7. Cody, S., Richardson, J. E., Rull, V., Ellis, C. \& Pennington, R. T. Ecography 33, 326-332 (2010).

8. Wang, L., Schneider, H., Zhang, X.-C. \& Xiang, Q.-P. BMC Plant Biol. 12, 210 (2012).

9. Sandel, B. et al. Science 334, 660-664 (2011).

10. Sedano, R. E. \& Burns, K. J. J. Biogeogr. 37, 325-343 (2010).

11. Castelltort, S. et al. Nature Geosci. 5, 744-748 (2012).

12. Hayes, F. E. \& Sewlal, J.-A. N. J. Biogeogr. 31, 1809-1818 (2004).

13. Barnes, J. B., Ehlers, T. A., Insel, N., McQuarrie, N. \& Poulsen, C. J. Geology 40, 1135-1138 (2012).

14. Hannisdal, B. \& Peters, S. E. Science 334, 1121-1124 (2011).

15. Mulch, A., Uba, C. E., Strecker, M. R., Schoenberg, R. \& Chamberlain, C. P. Earth Planet. Sci. Lett. 290, 173-182 (2010).

16. Higgins, M. A. et al. J. Biogeogr. 38, 2136-2149 (2011).

17. Hoorn, C. et al. Science 330, 927-931 (2010).

18. Figueiredo, J. Hoorn, C., van der Ven, P. \& Soares, E. Geology 37, 619-622 (2009)

19. Yeung, L. Y. et al. Geophys. Res. Lett. 39, L18609 (2012).

20. Benton, M. J. Science 323, 3667-3679 (2009).

21. Wegener, A. Petermanns Geogr. Mitt. 63, 185-195, 253-256, 305-309 (1912).

\section{Acknowledgements}

We thank CLIM-AMAZON (www.clim-amazon.eu), the Swedish and European Research Councils (StG \#311024) and LOEWE of the Hesse Ministry of Higher Education, Research and the Arts.

Carina Hoorn ${ }^{1 \star}$, Volker Mosbrugger ${ }^{2}$, Andreas Mulch ${ }^{2,3}$ and Alexandre Antonelli ${ }^{4 *}$ ${ }^{1}$ Paleo Ecology and Landscape Ecology, Institute for Biodiversity and Ecosystem Dynamics, University of Amsterdam, 1090 GE Amsterdam, The Netherlands, ${ }^{2}$ Senckenberg Gesellschaft für Naturforschung, 60325 Frankfurt, Germany, ${ }^{3}$ Biodiversität und Klima Forschungszentrum and Goethe University, 60325 Frankfurt, Germany, ${ }^{4}$ Gothenburg Botanical Garden and Department of Biological and Environmental Sciences, University of Gothenburg, 41319 Göteborg, Sweden.

*e-mail: M.C.Hoorn@uva.nl;

Alexandre.Antonelli@bioenv.gu.se;

Andreas.Mulch@senckenberg.de;

Volker.Mosbrugger@senckenberg.de 